\title{
A Review of Residential Schools and Indigenous People: From Genocide via Education to the Possibilities for Processes of Truth, Restitution, Reconciliation, and Reclamation Edited by Stephen James Minton
}

\author{
Valerie Mulholland \\ University of Regina
}

Stephen James Minton's (2020) edited collection Residential Schools and Indigenous People: From Genocide via education to the possibilities for processes of Truth, Restitution, Reconciliation, and Reclamation could not be a more timely publication for Canadian readers; however, the scope of the collection should resonate with readers across the continents. Since 2015, when the Truth and Reconciliation Commission of Canada (TRC) report was officially presented to Parliament, Canadians, whether willingly or not, have been engaged in the commission's 93 Calls to Action. I happened to be attending a national conference in Ottawa, when the launch occurred, staying at a hotel a few blocks from Parliament Hill. The hotel was full of excitement, large screens televising the proceedings a few blocks away, groups of Elders being guided on and off buses to attend special events around the city. One hotel employee confided that he was proud to work at the hotel, saying, "We're in the middle of history, these days." At the time, I thought the country was on the cusp of significant change, so I eagerly read this book. Comprised of nine chapters, by seven authors from various countries with equally shameful histories, Canada's legacy of residential schools is not included.

In bringing together Indigenous and non-Indigenous authors from Aotearoa/New Zealand, Australia, Greenland, Ireland, Norway, the United Kingdom, and the United States, this book marks an attempt to tell the stories of what happened to Indigenous people as a result of the interring of Indigenous children in residential schools, to say how and why the schools were set up and run, to document the patterns of abuse and neglect, and to examine the legacies that the residential schools systems have had on Indigenous peoples. (p. 1)

Absent from the collection, not because the Canadian history is different, but arguably because "a number of first-hand survivor accounts have already been written by Indigenous people who were interred in residential schools, particularly in Canada" (p. 4), which are listed in in the introduction and bibliography; furthermore, readers "with a specific interest in the Canadian experience is, therefore, referred to these aforementioned sources" (p. 5). The omission was deliberate, and consequently, a broader global perspective of residential schools was developed.

Justifying his role as an editor for such a project, given his own privileges, and naming his affinity for those who are marginalized, bullied, and oppressed, Minton wrote, "I do not believe that it is anyway justifiable to leave the addressing of the endemic problems and manifestations of individual and society disempowerment, and differential privilege, to the disempowered and non-privileged." He aspires to stand with, to ally, in the spirit of Patrick Lewis (2018) whom he quotes: "Ally is not an identity, it is an action" (p. 6).

Before I move on from the Canadian context, Minton deals at some length with issues related to the TRC. Canada is not absolved of any crimes, excused from accountability, or let off the hook. Citing Chrisjohn and Wasacase (2009), Minton provides a critique of the TRC's effects and intentions. "We must be acutely aware that the crimes of residential school systems cannot be reduced to the injuries experiences by surviving individuals - for residential schools systems 
were not aimed at individuals, but rather at peoples" (p. 11). Therefore, the genocide in the title of is an accurate frame for the substance of the content and stories included in the book.

Language and culture were the primary targets of Education by the State in all geographies where residential schools were constructed to subjugate peoples. Residential schools were designed to break familial and cultural ties and eradicate Indigenous languages, and were efficient mechanisms for implementing nation state policies in all contexts described. This is the central, organizing thematic thread of the collection. Under the guise of good intentions, most often phrased as acting "for the good of the child," a dangerous premise historically and to this day, residential schools functioned to dismantle families and communities, and create intergenerational alienation and trauma. Destructive policies and practices were taken up with vigour by all state actors. There are two outliers in the collection, the Sami of Norway and the Irish. Previously, I was accustomed to reading about the residential schools of North America, New Zealand and Australia. The focus on the Sami in Chapter 6 "The Colonization of Sapmi" was of particular personal interest because I knew almost nothing about their history, so reading the visceral stories of contemporary Sami survivors was very affecting. Christianity and colonization are either features or factors in each chapter, which is no shock to readers who will likely be drawn to this subject. Initially, I was skeptical about the decision to include Irish colonization, Chapter 8 "Punishing Poverty: The Curious Case of Ireland's Institutionalized Children." With even a smattering of European history, readers will acknowledge that the Irish were colonized by the British. Predictably, and the Irish residential schools were instrumental in enacting all manner of atrocities, similar to the other geographical contexts, highlighting poverty and persecution as the salient features of residential schools everywhere. I realized my own racialized bias in my initial hesitation. I was wrong.

With any edited collection, the issue of voice inevitably arises, and it's true for this book, too. Minton opens with his own introductory chapters, which are traditionally academic in voice and tenor. In terms of structure, Chapter 2 "Some Theoretical Touchstones' provides a conventional theoretical framework, a typology of genocide, and conditions for assessing outcomes of residential school regimes. The chapters that follow expand understanding in powerful ways with generous, grounded and deeply moving accounts of residential school experiences. Six other authors, either in partnership with Minton or others, build a complex picture with tones, approaches, and styles which taken as a whole work well. This scholarship could be described as theorizing for the future. Giving the last word to Tania Ka'al, Rosemary Norman-Hill and Natahnee Nuay Winder was a sound editorial choice. Their voices provided some hope and cultural clarity, a way to the future. In the concluding chapter, "Reflections," the authors ask

the reader to find their own truths within those stories and move to place that allows for restitution, reconciliation, and reclamation. While the stories are tragic, our storying will not remain in the "the tragic." For to do so disrespects and displaces the thousands of years of 'knowing, being, and doing' that our ancestors passed down through the ages to ensure a healthy future for our peoples. (213)

Recently, I visited a city on the edge of the geographical region of the historical fur trade in Western Canada and was struck by the goods on offer at local pawn shops. Two ceremonial drums sat in the glaring sun of a west-facing window. What level of historical amnesia would the buyer need to exchange money for a sacred drum? What circumstances would lead an individual to pawn a drum? Step back for a moment. The image of the drums in the pawn shop window are 
emblematic of the ongoing story of colonization, just as land acknowledgements and framed apologies are gestures of a nation attempting to exonerate blame for egregious injustices and colonial violence, of which residential schools are an integral part. I see this edited collection as a contribution toward the restitution, reconciliation, and reclamation that the authors seek to find.

\section{Reference}

Minton, S. J. (2020).Residential Schools and Indigenous People: From Genocide via Education to the Possibilities for Processes of Truth, Restitution, Reconciliation, and Reclamation. New York, NY: Routledge/Taylor and Francis Group 